\title{
Effects of carbon disulphide on the liver of rats
}

\author{
E. J. BOND, ${ }^{1}$ W. H. BUTLER, F. DE MATTEIS, AND J. M. BARNES \\ Toxicology Research Unit, M.R.C. Laboratories, Carshalton, Surrey
}

\begin{abstract}
Bond, E. J., Butler, W. H., de Matteis, F., and Barnes, J. M. (1968). Brit. J. industr. Med., 26, 335-337. Effects of carbon disulphide on the liver of rats. Normal rats surviving a single oral dose of carbon disulphide $\left(\mathrm{CS}_{2}\right)$ show liver enlargement and depression of drug-metabolizing enzymes but no liver necrosis. If the drug-metabolizing enzymes are stimulated by phenobarbitone before exposure to $\mathrm{CS}_{2}$, the $\mathrm{LD}_{50}$ does not change but liver necrosis is produced.
\end{abstract}

The toxic effects of carbon disulphide $\left(\mathrm{CS}_{2}\right)$ are well known and affect mainly the central and peripheral nervous systems, in some cases after damage to blood vessels. There is very little published work on the effects of $\mathrm{CS}_{2}$ on experimental animals, and no generally accepted idea on its precise mode of action (Brieger and Teisinger, 1967). It is known that $\mathrm{CS}_{2}$ is partly metabolized to dithiocarbamates, and conversely dithiocarbamates such as disulfiram (Antabuse) may be partly metabolized to release $\mathrm{CS}_{2}$. What role the metabolites play in initiating the pathological lesions is unknown.

This paper records the observations that pretreatment with a drug (phenobarbitone), which stimulates liver microsome enzyme activity, significantly alters the degree of liver cell damage produced by $\mathrm{CS}_{2}$. While the significance of this finding cannot yet be properly assessed, it is recorded and discussed briefly since it suggests that exposure of people to drugs or other chemicals might alter their response to $\mathrm{CS}_{2}$. The biochemical changes induced in the liver by single doses of $\mathrm{CS}_{2}$ are described in detail elsewhere (Bond and de Matteis, 1969).

\section{Materials and methods}

Male albino rats (150-180 g.) of the Porton strain, fed M.R.C. Diet 41B (Bruce and Parkes, 1956), were fasted

${ }^{1}$ Present address: Canadian Department of Agriculture Research Institute, London, Ontario, Canada. overnight before being given by mouth $\mathrm{CS}_{2} 1: 1$ in arachis oil. Control rats received arachis oil only.

Pretreatment by phenobarbitone involved two doses, six hours apart, of $50 \mathrm{mg}$. $/ \mathrm{kg}$. two days before and a single dose of $80 \mathrm{mg} . / \mathrm{kg}$. one day before the $\mathrm{CS}_{2}$. The drug, 2-diethylaminoethyl 2,2-diphenylbutyrate (SKF 525A), was used to depress the drug-metabolizing enzymes stimulated by phenobarbitone, and for this purpose $40 \mathrm{mg} . / \mathrm{kg}$. was given intraperitoneally 45 minutes before the carbon disulphide.

At autopsy tissues from the major organ were fixed in $10 \%$ formol saline. Paraffin sections were prepared in the usual fashion and stained with Harris's haematoxylin and eosin. Frozen sections were stained with oil red $\mathbf{O}$ for fat.

\section{Results}

Rats killed 24 hours after a dose of $1 \mathrm{ml} / \mathrm{kg}$. $\mathrm{CS}_{2}$ often had stomachs somewhat dilated with clear fluid, and might show moderate congestion with some haemorrhages into the lungs. The other organs appeared normal, and histologically no changes were found in the kidneys, spleen, pancreas, heart or adrenals. The liver weight of these animals was greater than that of fasted controls, but histologically little change was seen except for an increase in fat in the periportal zone. In the centrilobular zone of one animal a few cells with pyknotic nuclei and dense eosinophilic cytoplasm were present, but at no time was a zonal necrosis seen. In the remaining animals this change was not seen (Fig. 1). At a dose of 0.5 $\mathrm{ml}$./kg. no histological change was seen in the liver.

Rats pretreated with phenobarbitone showed no 


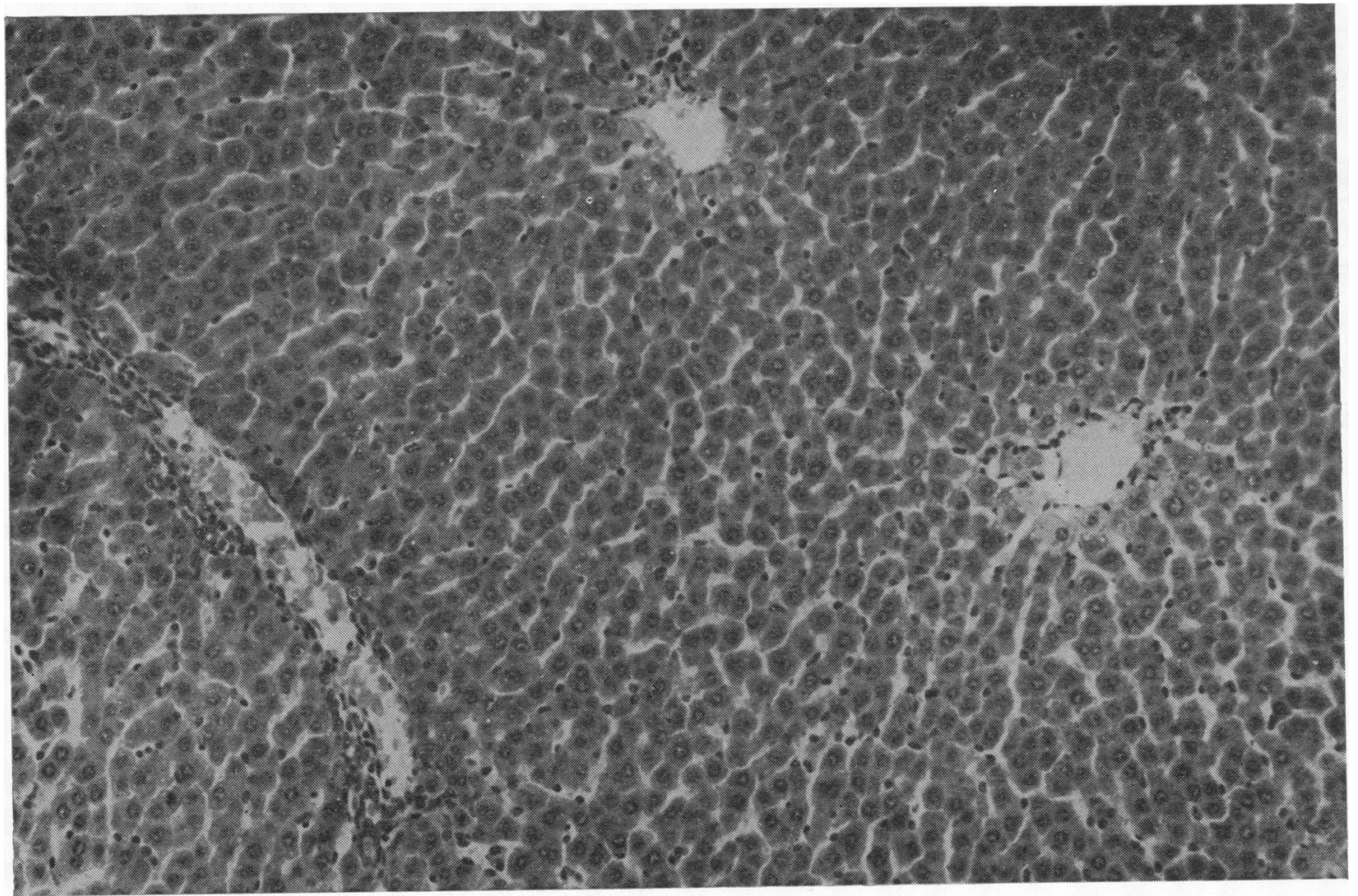

FIG. 1. Liver of rat killed 24 hours after treatment with carbon disulphide, $1 \mathrm{ml} . / \mathrm{kg}$., showing normal lobular pattern and no evidence of zonal necrosis. H. and E. $\times 160$.

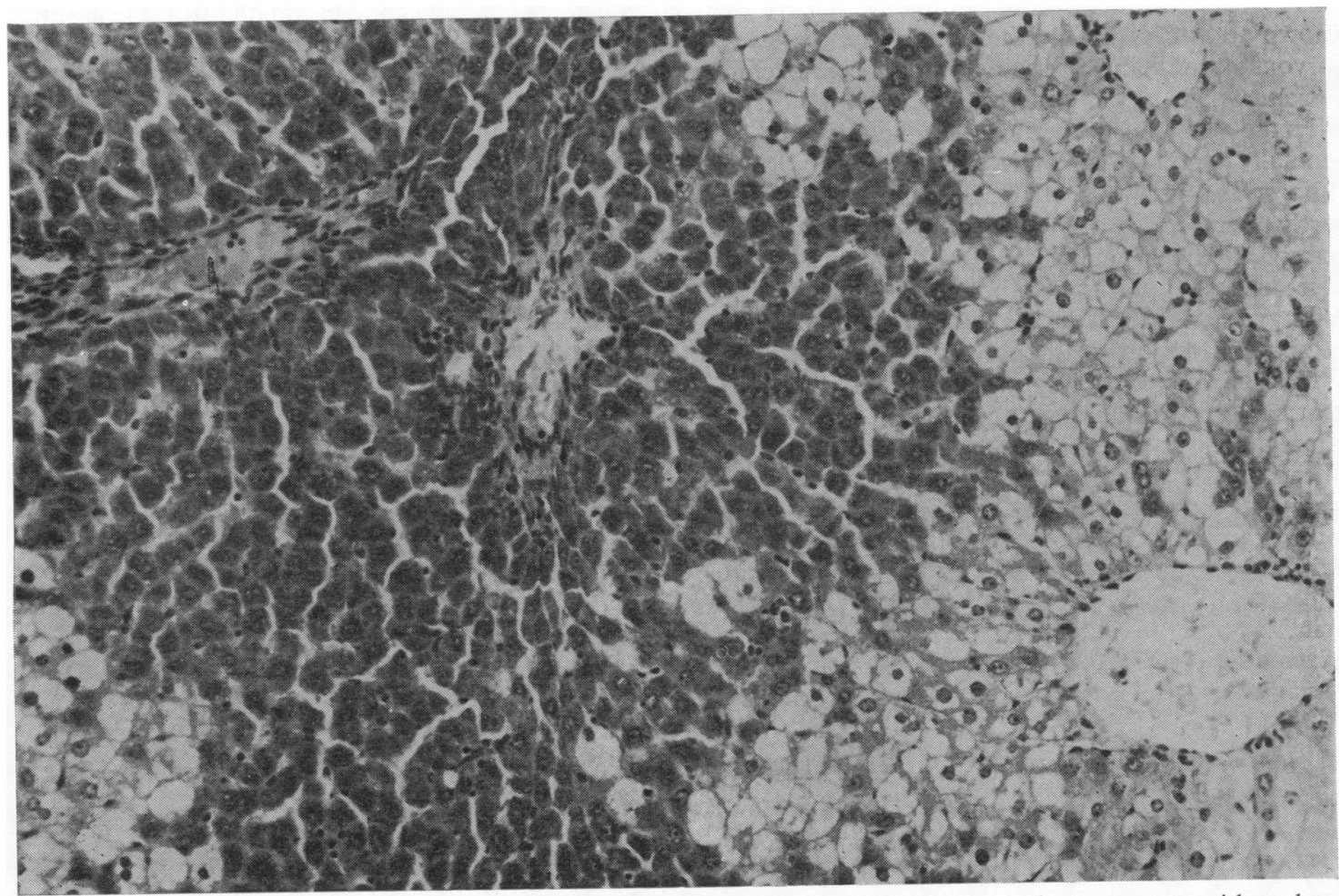

FIG. 2. Liver of rat pretreated with phenobarbitone for two days and killed 24 hours after treatment with carbon disulphide, $1 \mathrm{ml}$. $/ \mathrm{kg}$., showing extensive centrilobular necrosis and hydropic cell change. H. and E. $\times 160$. 
difference in their general behaviour after a single dose of $1 \mathrm{ml} . / \mathrm{kg}$. $\mathrm{CS}_{2}$, nor was the single dose $\mathrm{LD}_{50}$ of $\mathrm{CS}_{2}$ significantly changed. The most striking difference was the extent of cellular damage in the livers of these animals. At 24 hours there was an extensive centrilobular zone necrosis with a very marked hydropic change (Fig. 2). In the surrounding viable liver there was some increase in fat. An animal killed at 48 hours showed a well-developed centrilobular coagulative necrosis, but the hydropic cells were less evident. In the surrounding intact parenchymal cells, multiple mitotic figures were present. The lesion described here is very similar to that induced by carbon tetrachloride. That the production of liver damage was linked with an increased activity of the liver microsome enzymes is suggested by the experiments with the drug SKF 525A. This compound is said to depress the activity of the drugmetabolizing enzymes in the liver, and when it was given to rats that had been pretreated with phenobarbitone, $\mathrm{CS}_{2}$ no longer produced severe liver cell necrosis.

\section{Discussion}

It is impossible to interpret these experimental observations at the present time, and there is no evidence from very extensive human experience that liver damage forms part of the picture in acute or chronic poisoning by $\mathrm{CS}_{2}$. However, these observations do suggest that $\mathrm{CS}_{2}$, despite its chemical reactivity, only damages some cells after it has been enzymatically converted into a toxic metabolite. Any attempt to learn more about the mode of action of $\mathrm{CS}_{2}$ must take such a possibility into account.

\section{References}

Bond, E. J., and de Matteis, F. (1969). Biochemical changes in rat liver after administration of carbon disulphide, with particular reference to microsomal changes. Biochem. Pharmacol., in press.

Brieger, H., and Teisinger, J. (1967). Toxicology of Carbon Disulphide. Toxicology-Proc. of a Symposium, Prague, 1966, ed. Brieger and Teisinger. Excerpta med. Foundation Monograph Series. Amsterdam.

Bruce, H. M., and Parkes, A. S. (1956). Correspondence. J. Anim. Techns. Ass., 7, 54.

Received for publication March 6, 1969. 